\title{
Non-native plants exert strong but under-studied influence on fire dynamics
}

\author{
Clare E. Aslan ${ }^{1,2}$, Brett G. Dickson ${ }^{1,2}$ \\ I Landscape Conservation Initiative, 1395 S Knoles Dr., Northern Arizona University, Flagstaff, AZ 86011, USA \\ 2 Conservation Science Partners, 11050 Pioneer Trail, Ste 202, Truckee, CA 96161, USA \\ Corresponding author: Clare E. Aslan (clare.aslan@nau.edu)
}

Academic editor: S. Bacher | Received 14 February 2020 | Accepted 26 August 2020 | Published 8 October 2020

Citation: Aslan CE, Dickson BG (2020) Non-native plants exert strong but under-studied influence on fire dynamics. NeoBiota 61: 47-64. https://doi.org/10.3897/neobiota.61.51141

\begin{abstract}
Altered fire regimes are among the most destructive consequences of anthropogenic environmental change. Fires have increased in frequency in some regions, and invasion by fire-adapted non-native species has been identified as a major driver of this change, which results in a feedback cycle promoting further spread by the non-native species and diminishing occurrence of natives. We notice, however, that nonnative species are often invoked in passing as a primary cause of changing fire dynamics, but that data supporting this claim are rarely presented. We therefore performed a meta-analysis of published literature to determine whether a significant relationship exists between non-native species presence and increased fire effects and risk, examined via various fire metrics. Our analysis detected a strongly significant difference between fire metrics associated with non-native and native species, with non-native species linked to enhanced fire effects and risk. However, only 30 papers discussing this linkage provided data to support it, and those quantitative studies examined only eight regions, five biome types, and a total of 22 unique non-native taxa. It is clear that we are only beginning to understand the relationship between non-native species and fire and that results drawn from an extremely limited set of contexts have been broadly applied in the literature. It is important for ecologists to continue to investigate drivers of changing fire regimes as factors such as climate change and land use change alter native and non-native fuels alike.
\end{abstract}

\section{Keywords}

fire extent, fire frequency, fire intensity, flammability, fuels, meta-analysis, native species 


\section{Introduction}

Anthropogenic global change has far-reaching consequences. Biodiversity is directly threatened by extinctions (Purvis et al. 2000; Barnosky et al. 2011). At the same time and perhaps more subtly, ecological processes are being altered as a result of both biotic and abiotic ecosystem transformation (Pausas 1999; Cramer et al. 2001; Grimm et al. 2013; Kraaij et al. 2018). These changes affect an increasing number of species and ecological communities - boosting some populations and reducing others (Clavel et al. 2010). Changing fire regimes exemplify such changes in process: fires are becoming more frequent in some contexts, more intense in others, and larger in extent in still others (Brooks et al. 2004; Rogers et al. 2011; Pausas and FernándezMuñoz 2012; Balch et al. 2017; Schoennagel et al. 2017; Kelley et al. 2019). Each of these changes comes with significant potential to alter ecological systems and biodiversity as vulnerable species decline and other species replace them.

In places where fire has become more frequent in recent decades, fire regime changes are often the result of non-native species invasions increasing the local density of fine fuels, or of climate change bringing warmer temperatures and increasing the flammability of existing fuels (Wilson et al. 2010; Pyšek et al. 2012; Balch et al. 2013; Chambers et al. 2019). These drivers can also act synergistically (Bradley 2010). It can be difficult for native species in systems of low historical fire occurrence to recover after fire events, and decreases in native densities pave the way for increases in populations of non-native species that are adapted to frequent fires and capable of growing quickly following a burn event. This has occurred in, for example, the Sonoran Desert and the Great Basin of the western US, both of which have experienced invasion by Old World annual grasses bringing continuous fuels that recover readily after burning, replacing discontinuous and non-fire-adapted vegetation (Bradley and Mustard 2005; Balch et al. 2013; McDonald and McPherson 2013).

Such changes have been shown by multiple metrics to affect fire regimes (Brooks et al. 2004; Gill et al. 2013). Invasions have reduced the fire return interval at individual locations, impacting non-fire-adapted native plants and promoting still more invasion by non-natives (Van Wilgen and Richardson 1985; D'Antonio and Vitousek 1992; Le Maitre et al. 2014). Some non-native species also grow more quickly than natives because they lack the herbivores, competitors, and pathogens that would limit their growth in their regions of origin (Chun et al. 2010). Via these mechanisms, fires fueled by nonnatives have been shown to hinder native species' regeneration, damage native soils, and otherwise result in ecosystem transformation and the replacement of native species with non-natives (Brooks et al. 2004). Where fires have become more intense (i.e., there has been an increase in heat at the fireline), this may be the result of fuels buildup following extended fire suppression or exclusion (Fulé et al. 1997) or of increased flammability of fuels as a result of climate change, or a combination of these factors. Additionally, introduced species may provide fuels that burn with higher intensity than native fuels, impacting seeds and soils and impeding recolonization by native plant species (Lippincott 2000; Brooks 2002; Esler et al. 2008; Le Maitre et al. 2014). Increases in fire extent caused by widespread invasions can also fundamentally alter vegetation communities. Recovery 
after more extensive fire events can be delayed because seed or plant sources for such recovery are located a greater distance away (Cansler and McKenzie 2014). After severe fires, bare ground can persist for a longer period because of this distance, again promoting colonization by non-native weedy species that demonstrate disturbance-adapted traits enabling them to colonize sites with poor or eroded soils (Moles et al. 2008).

These changes in fire patterns can impact native biodiversity, ecological functions, and ecosystem resilience following disturbances (Johnstone et al. 2016). For example, non-native species that supply large quantities of flammable fine fuels may be promoted both by climate change and the fire cycle they perpetuate, generating feedback loops that can transform desert ecosystems into invasive grasslands (Abatzoglou and Kolden 2011). Heavily altered fire patterns can lead to degraded landscapes with reduced potential to support management objectives such as livestock grazing, conservation, recreation, and watershed maintenance (Allen et al. 2002). As a result, it is imperative for decision-makers and land managers to understand the key drivers of current changes in fire patterns so such changes can be better anticipated and prevented. This has led to increased focus on non-native species as sources of novel fuels and drivers of increased fire frequency and fire intensity (D’Antonio and Vitousek 1992; Brooks et al. 2004).

Although the link between non-native invasion and problematic shifts in fire is oftcited in global change literature as an important invasion-fire cycle (e.g., D'Antonio and Vitousek 1992; Rossiter et al. 2003; Balch et al. 2013), that linkage depends on conditions that are not present in all systems at all times. Specifically, to alter fire regimes, invasion must alter fuels and/or flammability, thus altering fire frequency, intensity, or extent (Brooks et al. 2004; Bowman et al. 2011; Underwood et al. 2019; Bishop et al. 2020). Not all invasions result in such changes, which rely on characteristics of both the non-native species and the native communities. For any specific fire, for example, unusual precipitation and drought patterns associated with climate change may be as likely to result in increased biomass production and subsequent drying for native plant species as for non-native plant species (Liu and Wimberly 2016).

To understand how consistently non-natives have been quantitatively associated with increased fire effects and risk, we performed a meta-analysis of published quantitative studies examining the effect of non-native vs native plants on fire characteristics. Our goals were: (a) to determine whether non-native species, relative to functionally similar native species, quantitatively and consistently increase metrics of fire effects and risk in ecosystems, and (b) to gauge the range of contexts over which this has been quantitatively analyzed, in order to consider how broadly assumptions regarding these patterns can justifiably be applied. For this study, we define "fire metrics" as those quantifiable descriptors of fire patterns that can be compared across studies (i.e., fire frequency, fire intensity, flammability, fuels quantity, and fire spatial extent). Note that there have been previous meta-analyses that have examined related but different questions, contributing to our understanding of the link between fire and non-native species. Jauni et al. (2015) performed a meta-analysis examining the effect of disturbance on non-native species and found that fire events resulted in increased diversity of non-natives. Alba et al. (2015) found through meta-analysis that exotic species composition and performance were both enhanced following wildfires but not following prescribed burns. 


\section{Methods}

To perform our meta-analysis, we began by searching ISI Web of Science (with coverage of years 1900-present) to find records of studies that have quantitatively compared non-native and native species' effects on fire metrics. We used the search terms fire + each of the following: plant + (native* OR exotic* OR non-native* OR alien* OR invasive*); plant + "functional group"; native + (tree* OR shrub* OR perennial grass* OR annual grass*); (severity OR frequency OR intensity OR extent) + (cause* OR attribute*), and applied them to all years inclusive. Additionally, we examined the Literature Cited sections of relevant papers to find additional studies - including from sources not referenced in Web of Science - that might contain relevant quantitative information. Searches were performed in summer 2020.

Although our search terms netted hundreds of references, only papers meeting the following criteria were useful in our meta-analysis: (1) they compared fire metrics stemming from native species (as a control group) with fire metrics stemming from non-native species; (2) they presented comparisons between the metrics of fire associated with native and non-native species from the same plant functional groups; (3) they included quantitative and original fire metrics. Many papers referenced fire effects in discussions of non-native species but did not include original quantitative information. Many other papers examined the effects of fire on non-native species (e.g., reporting experiments examining control measures for non-natives), but we sought the opposite metric: the effect of non-native species on fire. For each of the studies that suited our criteria, we derived from the reports treatment (effect of non-natives) and control (effect of natives) fire metrics as well as sample sizes and measures of variance for treatments and controls.

Across all of the studies we included in our analysis, fire metrics were the response variables of interest. However, there are many ways to measure the effect of a given factor (e.g., non-native fuels) on fire. We were able to include all of these in one common metaanalysis framework by using the ratio of means (ROM) to compare the treatment and control effects of all studies (Hedges et al. 1999; Schwartz et al. 2012). The ratio of means is calculated as the natural $\log$ of the quotient of the mean outcome from the experimental group divided by the mean outcome from the control group (Hedges et al. 1999). To parameterize the response ratio, we derived from each paper the average native vs. nonnative plant effects on fire metrics; in the set of relevant studies we found, these metrics included fire frequency, fire intensity (i.e., heat at the fireline), fuels quantity (including biomass production, relative growth rate, and litter production), spatial extent, and flammability (including fuels moisture, heat of combustion, and volatility). We then calculated the natural $\log$ of the ratio of the experimental mean to the control mean fire metric within each study. The resulting set of ROMs, including ratios from all studies meeting our meta-analysis criteria, formed the set of values included in our analyses.

Categorical analysis can be used to further explore the population of studies included in the overall meta-analysis in order to ascertain whether significant treatment effects persist within certain limited contexts. As long as a given category is represented by at least two studies, it is possible to examine it separately from the other categories to measure the strength of the treatment effect within that categorical context. The categories 
we examined as such included: biome type, geographic region, plant functional group, and fire effect metric. Because the total number of studies within each category was not always greater than 1 , the total number of studies included in categorical analyses did not always equal the total number of studies included in the overall meta-analysis.

In meta-analyses, studies included in the calculation of effect sizes are weighted more heavily if they used a larger sample size in the original research. We included the variances and sample sizes of all studies in our response ratio meta-analysis by calculating fixed and random effects estimates and applying inverse variance weighting, thus allowing studies with larger sample sizes to carry greater influence on the effect estimates. We calculated heterogeneity $Q$ statistics to evaluate whether effect sizes are homogeneous or, conversely, are suggestive of underlying unexplained structure in the data (Rosenberg et al. 2000). Using these models, we estimated effect size means and confidence intervals for the full meta-analysis as well as for categorical analyses of subgroups. As long as ROM means and confidence intervals exclude the value of 1 , they can be considered significant effect sizes. We performed all calculations using the meta package in $\mathrm{R}$ version 3.6.3 (R Core Team 2020). For the overall model, significance was accepted at alpha $=0.05$.

An important consideration in meta-analysis is that researchers and journals may be less inclined to publish studies that fail to show the expected effect, either because the results were non-significant (in our case, finding no difference between native and non-native species and their effects on fire metrics) or because they were significant in the opposite direction from predicted (in our case, finding that native species enhanced fire metrics more than non-native species). To estimate the potential quantitative effect of this phenomenon, we calculated a fail-safe analysis, which we performed using the trimfill function in the meta $\mathrm{R}$ package. Results indicated whether the outcome of our overall meta-analysis was likely affected by a lack of publication or "file drawer" problem and also estimated the likely overall effect size after producing a correction for such a publication bias. Note that sample sizes were not sufficient to conduct a similar fail-safe analysis for subgroup categories.

\section{Results}

Our search terms yielded 612 unique sources. We examined each of these for methodology and found only 30 papers, reporting results of 41 distinct studies, that included a usable quantitative comparison of the effects of native vs non-native species on fire metrics. This final sample of relevant papers displayed the following breakdown by subgroup categories: by region, nine studies took place in the Southwestern US, three in mediterranean California, five in the Western US more broadly, eight in Australia, six in the Eastern US, one in Europe, three in South Africa, and six in South America. By biome, six studies were performed in deciduous forest, 10 in desert, 16 in mediterranean systems, eight in savanna, and one in mixed shrubland/woodland. Functional groups included annual grasses ( 9 studies), forbs (1 study), perennial grasses (20 studies), shrubs (3 studies), and trees (6 studies). A total of five usable studies combined data from multiple species to report fire metrics of non-native vs native species, making it impossible to extract the contributions of individual species but allowing comparison between those two groups. 
Table I. The 16 species examined at the species level in quantitative comparisons of fire metrics stemming from native vs. non-native fuels, and key traits related to effects. Five analyzed studies compared groups of native vs non-native species and thus effects could not be ascribed to individual species, and these studies are excluded from this table.

\begin{tabular}{|c|c|c|}
\hline Species & Traits related to fire effects in meta-analysis & Citation \\
\hline $\begin{array}{l}\text { Ampelodesmos } \\
\text { mauritanica }\end{array}$ & $\begin{array}{l}\text { Resprouts quickly after fire; produces flammable biomass } \\
\text { more rapidly than native species }\end{array}$ & Grigulis et al. 2005 \\
\hline Andropogon gayanus & High growth potential relative to native species & Bilbao and Medina 1990 \\
\hline Bromus hordeaceus & $\begin{array}{l}\text { Low quality litter decomposed less than native litter, } \\
\text { contributing to regional fuels for a longer period of time; } \\
\text { compared with native species, sustains dry biomass for a } \\
\text { larger portion of the year }\end{array}$ & Hernández et al. 2019 \\
\hline Bromus rubens & $\begin{array}{c}\text { Winter annuals that escape extreme summer heat, generating } \\
\text { high fuel load production relative to native species }\end{array}$ & Brown and Minnich 1986 \\
\hline Bromus tectorum & $\begin{array}{l}\text { Exploits soil water following fire, outcompeting natives in } \\
\text { regeneration }\end{array}$ & Melgoza et al. 1990 \\
\hline Cenchrus ciliaris & Increases fuel loads relative to native species & Miller et al. 2010 \\
\hline Cytisus scoparius & Higher relative growth rate than native species & Fogarty and Facelli 1999 \\
\hline Eragrostis lehmanniana & Much faster biomass production than native species & Anable et al. 1992 \\
\hline Hakea sericea & Increased fuel loads relative to native species & $\begin{array}{l}\text { Van Wilgen and } \\
\text { Richardson } 1985\end{array}$ \\
\hline Hyparrhenia rufa & Higher growth rates in fertile sites, relative to native species & Baruch et al. 1985 \\
\hline Imperata cylindrica & $\begin{array}{l}\text { Increased fuel loads and fuel continuity relative to native } \\
\text { species }\end{array}$ & Lippincott 2000 \\
\hline Melinus minutiflora & Higher growth rates in fertile sites, relative to native species & Baruch et al. 1985 \\
\hline Pennisetum setaceum & Increased fuel loads relative to native species & Rahlao et al. 2009 \\
\hline Pinus contorta & $\begin{array}{l}\text { Increased vertical fire continuity and increased flammability } \\
\text { of fuels relative to comparison native species }\end{array}$ & Cóbar-Carranza et al. 2014 \\
\hline Schinus terebinthifolius & Reduces fire frequency ecosystem-wide & Stevens and Beckage 2009 \\
\hline Tamarix sp. & Rapid biomass accumulation and rapid regrowth after fire & Ellis et al. 1998 \\
\hline
\end{tabular}

Overall, our meta-analysis detected a strong, statistically significant link between non-native species and increased fire effect (random-effects model $R O M=2.21 ; 95 \%$ bias-corrected $C I 1.52$ to $3.20 ; n=41 ; p<0.0001$ ). Heterogeneity was also significant $\left(Q_{T}=5.68 \times 10^{5}, d f=40, p<0.0001\right)$, which highlights the large amount of unexplained data structure in the dataset. The many different approaches to comparing fire stemming from natives and non-natives that were employed by the various studies we examined likely contributed to this heterogeneity, emphasizing the importance of subgroup comparisons. The relevant studies found for this analysis contained clear evidence of a link between non-native species and enhanced fire metrics. However, the total number of species and the total number of contexts covered is extremely limited. The 41 studies reported species-level fire metrics reported for only 16 taxa (Table 1). Usable studies took place in only eight regions and four biome types (Table 2).

The significant response ratio of non-natives to natives held across almost all examined subgroups, as well. Among metrics of fire effects and risk, non-natives generated significantly higher fire metrics of flammability (random-effects model $R O M=$ 1.50; $95 \%$ bias-corrected $C I 1.39$ to $\left.1.62 ; n=15 ; \mathrm{Q}_{\mathrm{B}}=1923.69\right)$, fuels $(R O M=2.27$; $C I 1.30$ to $\left.3.97 ; n=18 ; \mathrm{Q}_{\mathrm{B}}=6.48 \times 10^{4}\right)$, and spatial extent $(R O M=10.02 ; C I 3.19$ to 
Table 2. Usable studies took place in eight regions and four biome types.

\begin{tabular}{|c|c|c|}
\hline Region & Biome type & Study \\
\hline \multirow[t]{7}{*}{ Southwestern US } & Savanna & Anable et al. 1992 \\
\hline & \multirow[t]{6}{*}{ Desert } & Brooks 1999 \\
\hline & & Brown and Minnich 1986 \\
\hline & & Busch 1995 \\
\hline & & Eilts and Huxman 2013 \\
\hline & & Ellis et al. 1998 \\
\hline & & Stevens and Fehmi 2009 \\
\hline \multirow[t]{5}{*}{ Western US } & \multirow[t]{3}{*}{ Savanna } & Balch et al. 2013 \\
\hline & & James and Drenovsky 2007 \\
\hline & & Wilsey and Polley 2006 \\
\hline & \multirow[t]{2}{*}{ Desert } & Melgoza et al. 1989 \\
\hline & & Whisenant 1990 \\
\hline \multirow[t]{5}{*}{$\overline{\text { Australia }}$} & \multirow[t]{5}{*}{ Mediterranean } & Fisher et al. 2009 \\
\hline & & Fogarty and Facelli 1999 \\
\hline & & Miller et al. 2010 \\
\hline & & Rossiter et al. 2003 \\
\hline & & Setterfield et al. 2010 \\
\hline \multirow[t]{3}{*}{ Eastern US } & \multirow[t]{3}{*}{ Deciduous forest } & Dibble et al. 2007 \\
\hline & & Lippincott 2000 \\
\hline & & Stevens and Beckage 2009 \\
\hline Europe & Mediterranean & Grigulis et al. 2005 \\
\hline \multirow[t]{2}{*}{ California } & \multirow[t]{2}{*}{ Mediterranean } & Keeley 2001 \\
\hline & & Keeley and Brennan 2012 \\
\hline \multirow[t]{2}{*}{ South Africa } & \multirow[t]{2}{*}{ Mediterranean } & Rahlao et al. 2009 \\
\hline & & Van Wilgen and Richardson 1985 \\
\hline \multirow[t]{2}{*}{ South America } & \multirow[t]{2}{*}{ Savanna } & Baruch et al. 1985 \\
\hline & & Bilbao and Medina 1990 \\
\hline
\end{tabular}

$31.48 ; n=2 ; \mathrm{Q}_{\mathrm{B}}=30.30$ ) (Fig. 1). Fire frequency did not differ significantly between native and non-native species $\left(R O M=2.22 ; C I 0.30\right.$ to $\left.16.43 ; n=5 ; \mathrm{Q}_{\mathrm{B}}=1544.80\right)$ (Fig. 1). Among biomes, non-natives generated significantly higher fire metrics for deserts $\left(R O M=3.02 ; C I 2.17\right.$ to $\left.4.20 ; n=10 ; \mathrm{Q}_{\mathrm{B}}=1532.06\right)$ and mediterranean biome $\left(R O M=2.82 ; C I 2.54\right.$ to $\left.3.14 ; n=16 ; \mathrm{Q}_{\mathrm{B}}=2376.90\right)$, but not for savannas $(R O M=$ $1.60 ; C I 0.48$ to $\left.5.28 ; n=8 ; \mathrm{Q}_{\mathrm{B}}=2.26 \times 10^{5}\right)$, or deciduous forests $(R O M=1.04$; CI 0.90 to $1.19 ; n=6 ; \mathrm{Q}_{\mathrm{B}}=26.76$ ) (Fig. 2).

Among functional groups, non-natives generated significantly higher fire metrics for perennial grasses $\left(R O M=2.53 ; C I 1.55\right.$ to $\left.4.10 ; n=20 ; \mathrm{Q}_{\mathrm{B}}=4.66 \times 10^{4}\right)$, shrubs $(R O M=$ $1.41 ; C I 1.34$ to $\left.1.49 ; n=3 ; \mathrm{Q}_{\mathrm{B}}=0.27\right)$, trees $\left(R O M=1.73 ; C I 1.51\right.$ to $1.99 ; n=6 ; \mathrm{Q}_{\mathrm{B}}=$ $1695.02)$, and annual grasses $\left(R O M=2.39 ; C I 1.24\right.$ to $\left.4.60 ; n=9 ; \mathrm{Q}_{\mathrm{B}}=1 . \times 10^{4}\right)$ (Fig. $3)$. Finally, among regions, non-natives generated significantly higher fire metrics for the Southwestern US $\left(R O M=3.85 ; C I 1.80\right.$ to $\left.8.21 ; n=9 ; \mathrm{Q}_{\mathrm{B}}=2.10 \times 10^{4}\right)$, Australia $\left(R O M=3.65 ; C I 2.77\right.$ to $\left.4.81 ; n=8 ; \mathrm{Q}_{\mathrm{B}}=132.71\right)$, South Africa $(R O M=1.78 ; C I 1.14$ to $\left.2.78 ; n=3 ; \mathrm{Q}_{\mathrm{B}}=29.49\right)$, and South America $(R O M=1.59 ; C I 1.38$ to $1.83 ; n=6$; $\left.\mathrm{Q}_{\mathrm{B}}=2515.47\right)$, but not for the Eastern US $\left(R O M=1.04 ; C I 0.90\right.$ to $1.19 ; n=6 ; \mathrm{Q}_{\mathrm{B}}=$ 26.76), California $\left(R O M=3.25 ; C I 0.66\right.$ to $\left.15.94 ; n=3 ; \mathrm{Q}_{\mathrm{B}}=460.80\right)$, or Western US $\left(R O M=1.06 ; C I 0.40\right.$ to $\left.2.80 ; n=5 ; \mathrm{Q}_{\mathrm{B}}=1.01 \times 10^{4}\right)($ Fig. 4$)$. 


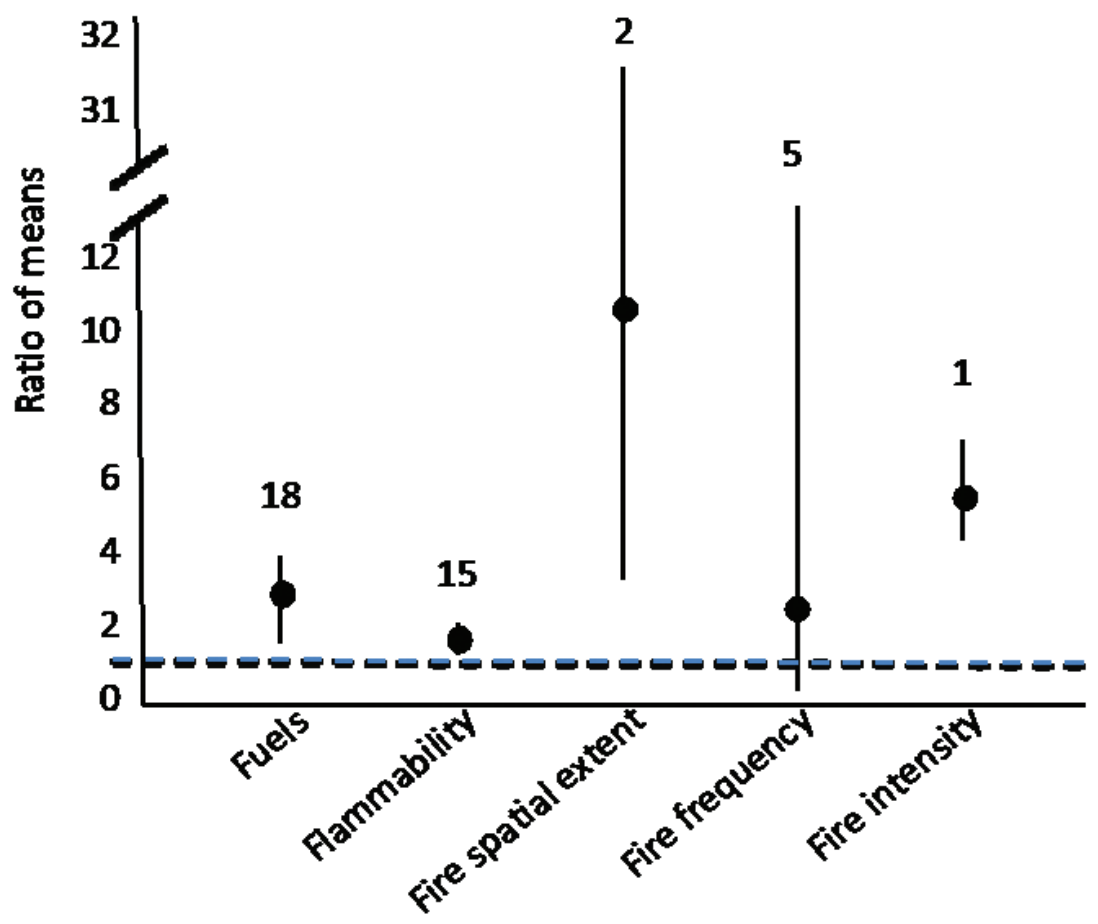

Figure I. Ratios of means (dark circles) and 95\% confidence intervals (denoted by lines) for fire metric subgroups analyzed using Hedges' $\mathrm{d}$ response ratios. Positive means and confidence intervals excluding 1 (indicated by a dashed, horizontal line) can be considered to indicate significantly higher fire metrics for native than non-native species. Sample sizes of each subgroup are denoted with numerals above each line.

The fail-safe analysis detected a significant file drawer problem $(t=-2.49 ; d f=39$; $p=0.017)$. Upon correcting for this problem via an estimate of the effect size in the absence of a file-drawer problem, the trimfill recommended analysis assumed an addition of 19 non-significant studies but predicted that with such studies included the overall effect would remain significant $(R O M=5.46 ; C I 3.83$ to $7.77 ; p<0.0001)$ and that the link between non-native species and increased fire metrics would persist.

\section{Discussion}

Our meta-analysis found a significant link between non-native plant species and fire metrics broadly, and specifically found that non-natives are associated with increased fuels, fire intensity, flammability, and fire extent, compared with native plant species, where the two have been contrasted. That is, quantitative research finds evidence that non-natives alter fire regimes by shifting the characteristics, quantity, and/or flammability of fuels. At the same time, our search terms netted a very small number 


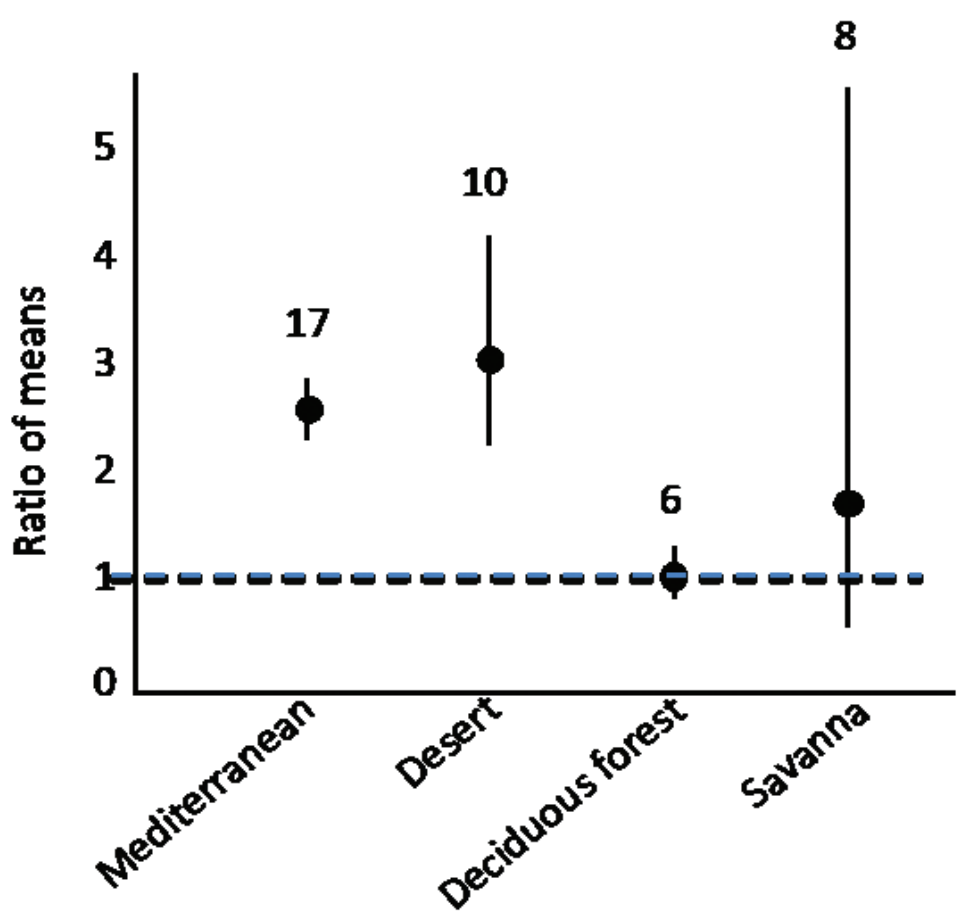

Figure 2. Ratios of means (dark circles) and 95\% confidence intervals (denoted by lines) for biome subgroups analyzed using Hedges' $\mathrm{d}$ response ratios. Positive means and confidence intervals excluding 1 (indicated by a dashed, horizontal line) can be considered to indicate significantly higher fire metrics for native than non-native species. Sample sizes of each subgroup are denoted with numerals above each line.

of quantitative studies examining an even smaller number of species. Approximately a twentieth of the studies that met our search criteria compared native and non-native plant species quantitatively; most of the others simply referenced the relationship between non-natives and fire.

Together, these results suggest that we are only beginning to understand the role of non-native species in fire regimes under environmental change, globally. Effects are quite strong where they have been quantitatively analyzed, but analyses have been limited to a few contexts. By one estimate, there are almost 17,000 species that have been established outside their native range (Seebens et al. 2017). As of 2016, just under 5,000 plant species were classified as "invasive," suggesting that they exert a negative impact in the systems where they are introduced (Kew 2016). It is clear that the 16 taxa included in these studies are merely a fraction of all invasive species, and the effects of the remainder of those species on fire have not been examined with reference to native species. In most cases, the difference in fire conditions between sites before and after invasion is unknown. Since fire interacts with other environmental change drivers, in addition to biological invasion, the future consequences of many invasions remain uncertain or unpredictable. 


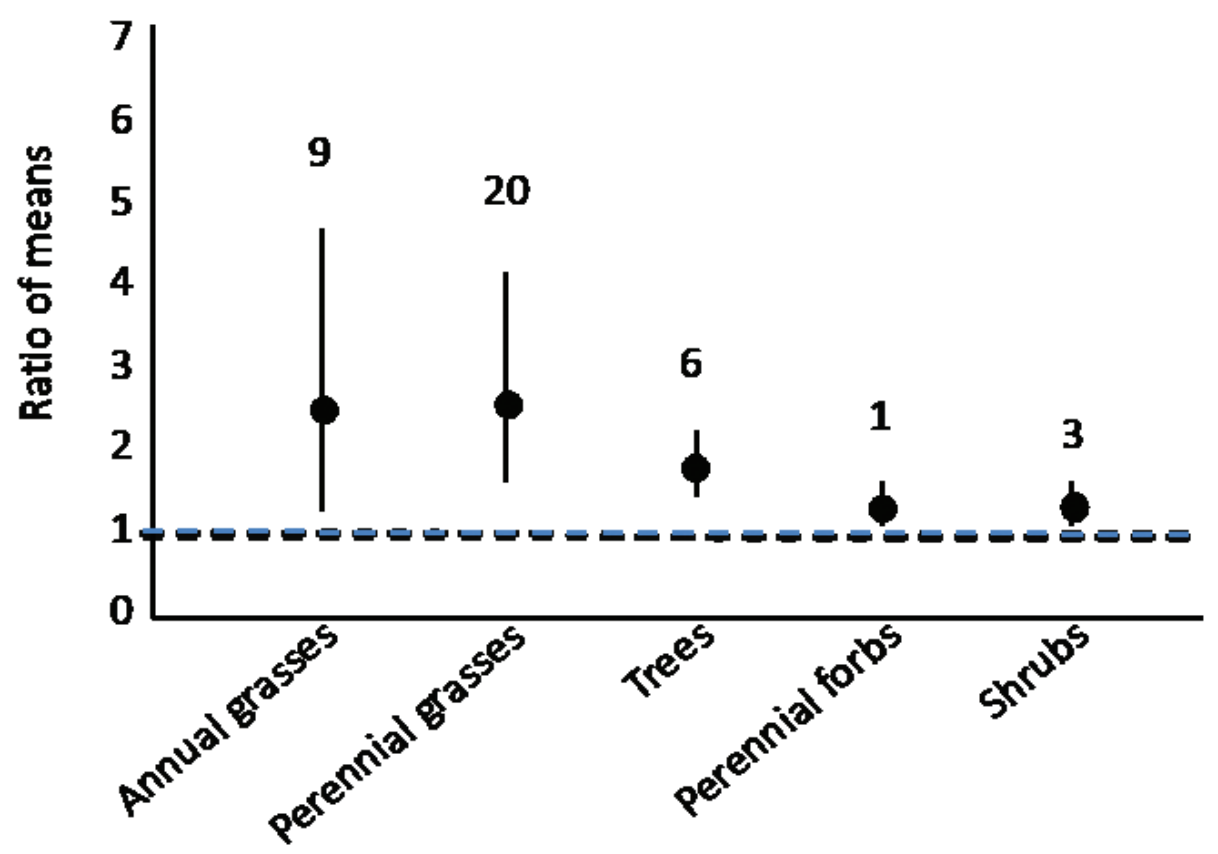

Figure 3. Ratios of means (dark circles) and 95\% confidence intervals (denoted by lines) for functional group subgroups analyzed using Hedges' $d$ response ratios. Positive means and confidence intervals excluding 1 (indicated by a dashed, horizontal line) can be considered to indicate significantly higher fire metrics for native than non-native species. Sample sizes of each subgroup are denoted with numerals above each line.

The 16 taxa that were examined at a species level in these studies included annual and perennial grasses, trees, shrubs, and a forb. Nearly all of them contributed to increases in fire metrics; the sole exception was Schinus terebinthifolius, which is associated with decreased fire frequency that promotes further invasion by this non-native tree (Stevens and Beckage 2009). In the quantitative research reviewed here, higher biomass production relative to native species were associated with the grasses Ampelodesmos mauritanica, Andropogon gayanus, Bromus rubens, B. tectorum, Cenchrus ciliaris, Eragrostis lehmanniana, Hyparrhenia rufa, Imperata cylindrica, Melinus minutiflora, and Pennisetum setaceum (Table 1). Similarly, the shrubs Cytisus scoparius and Hakea sericea and trees in the genus Tamarix were associated with increased fuels production relative to native species (Table 1). Other important factors included continuity and flammability of fuels (for example, Pinus contorta exhibited greater vertical continuity and volatility of biomass than did comparison native species; Cóbar-Carranza et al. 2014), as well as phenological drivers; B. rubens, for example, accumulated biomass during the winter months and thereby escaped damage from extreme summer heat and produced higher total fuels than comparison natives (Brown and Minnich 1986) (Table 1). In each case where fire frequency was increased 


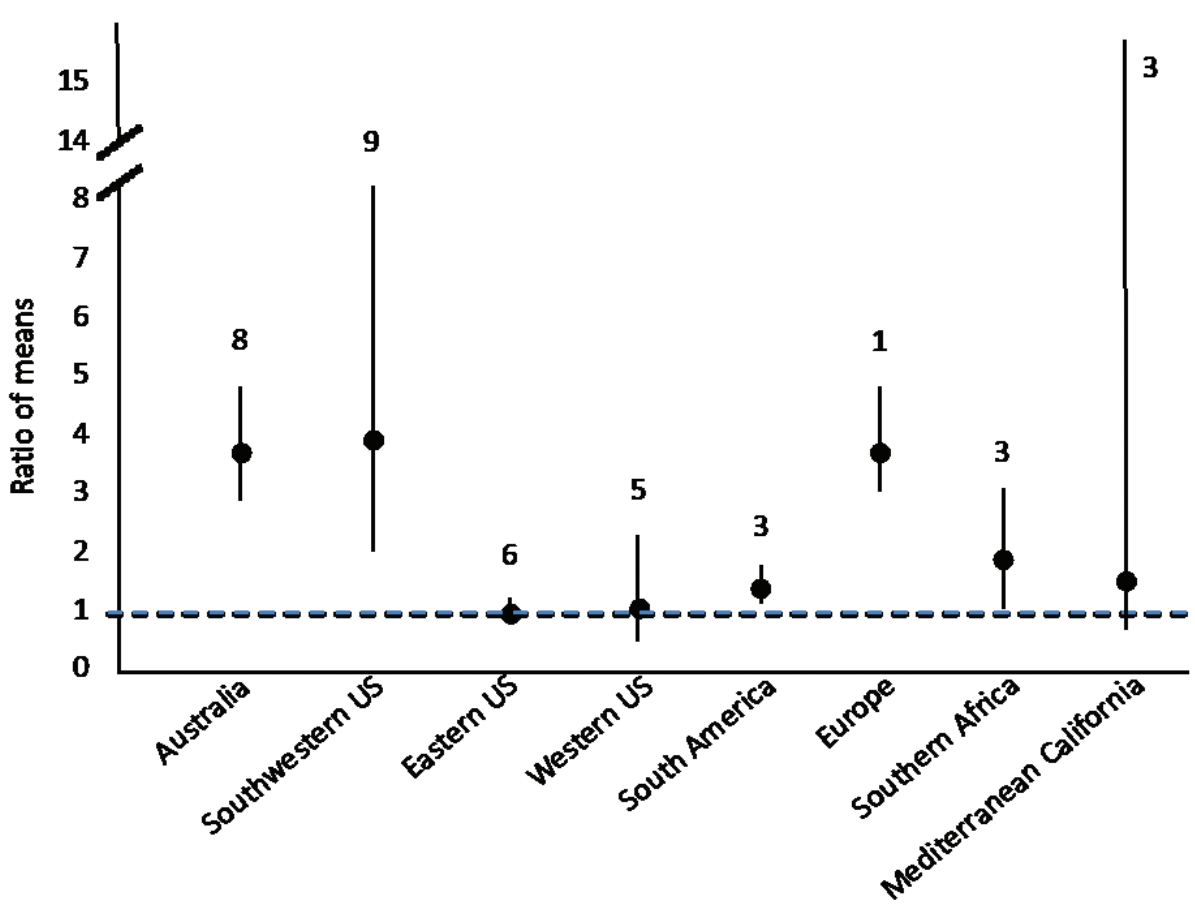

Figure 4. Ratios of means (dark circles) and 95\% confidence intervals (denoted by lines) for region subgroups analyzed using Hedges' $\mathrm{d}$ response ratios. Positive means and confidence intervals excluding 1 (indicated by a dashed, horizontal line) can be considered to indicate significantly higher fire metrics for native than non-native species. Sample sizes of each subgroup are denoted with numerals above each line.

by the presence of non-native species, the critical factor distinguishing invaded sites from non-invaded sites was the exceptional continuity (in space or over time) of fuels produced by the non-natives, increasing fire frequency and risk.

Non-native plants have led to novel fire disturbances in the studied systems. Our results demonstrated that fires in invaded sites recur with greater frequency, burn with higher fireline intensity, or burn over greater extent than in native-dominated sites. Such systems are subject to significant ecological transformation: when native species are non-fire-adapted or unable to recover from severe fires, a positive invasive speciesfire feedback cycle emerges (D’Antonio and Vitousek 1992; Rossiter et al. 2003). This cycle can threaten native communities over very large areas, fundamentally reshaping ecosystems and ushering in alternative, non-native-dominated stable states (e.g., Brooks et al. 2003; Godfree et al. 2017).

Altered fire regimes are evidently a strong component of global change. Furthermore, they interact with other drivers of environmental change. Climate change alone can boost the growth rate (i.e., production and thus total quantity of fuels) and flammability of biomass both native and non-native (Myneni et al. 1997; Westerling et al. 2006; McGranahan et al. 2018). Unusual fire patterns stemming from climate change 
may or may not depend on non-native species invasion, although system-specific characteristics (such as historical fire frequency, timing of precipitation, and fire adaptations among native species) may elevate the likelihood that non-native fuels carry particular significance during any given fire year. Land use changes and resulting increases in human footprints in natural areas can also transform fire regimes, increasing the rate of intentional and accidental ignitions (e.g., 95\% of all annual ignitions in California are caused by humans; Syphard et al. 2008).

Disentangling the effects of climate change, land use, and non-native fuels will be important for spatially-explicit fire risk assessment and management and restoration decision-making (Gray et al. 2014; Westerling 2016; Balch et al. 2017; Syphard et al. 2017). Improved forecasting to guide such assessments will require continued and extended research of the quantitative fire metrics associated with non-native species across functional groups, regions, and biome types, as well as the response of those fire metrics to climate change and land use change. As conditions change in any given system, the relative fire risk driven by each of these factors is also likely to change (McWethy et al. 2013). Classic adaptive management requires sequential use of management activities to meet certain objectives, and also requires careful study of the effectiveness of each activity (Holling 1978; Gunderson 1999; Williams and Brown 2012), highlighting the importance of continued research in complex systems. Study of the relative roles of native vs non-native plants in fire regimes within any particular location will be necessary to facilitate effective management decisions over time.

\section{Conclusions}

Global change today consists of multiple drivers operating both individually and in synergy. The combined influence of biological invasions, land use change, and climate change can result in dramatic changes in fire dynamics within particular systems, yet understanding how each driver contributes to fire regime change is essential for effective management decision-making in response. Our study identified a clear role of non-native species in increased fire metrics, but also highlighted the limited scope of our understanding - only a small number of species and systems have been quantitatively examined to this point. Both native and non-native fuels must be considered in light of changing climatic patterns and land uses, and increased empirical assessment of the respective roles of climate, land use, and invasion are necessary for appropriate responses.

\section{Acknowledgements}

We thank M. Gray, L. Zachmann, C. Levine, and two anonymous reviewers for key discussions and thoughtful reviews of early drafts of this manuscript. This work was supported by Joint Fire Science Program Award \#15.232. 


\section{References}

Abatzoglou JT, Kolden CA (2011) Climate change in western US deserts: potential for increased wildfire and invasive annual grasses. Rangeland Ecology \& Management 64: 471-478. https://doi.org/10.2111/REM-D-09-00151.1

Alba C, Skálová H, McGregor KF, D’Antonio C, Pyšek P (2015) Native and exotic plant species respond differently to wildfire and prescribed fire as revealed by meta-analysis. Journal of Vegetation Science 26: 102-113. https://doi.org/10.1111/jvs.12212

Allen CD, Savage M, Falk DA, Suckling KF, Swetnam TW, Schulke T, Stacey PB, Morgan P, Hoffman M, Klingel JT (2002) Ecological restoration of southwestern ponderosa pine ecosystems: a broad perspective. Ecological Applications 12: 1418-1433. https://doi. org/10.1890/1051-0761(2002)012[1418:EROSPP]2.0.CO;2

Anable ME, McClaran MP, Ruyle GB (1992) Spread of introduced Lehmann lovegrass Eragrostis lehmanniana Nees. in southern Arizona, USA. Biological Conservation 61: 181-188. https://doi.org/10.1016/0006-3207(92)91114-8

Balch JK, Bradley BA, Abatzoglou JT, Nagy RC, Fusco EJ, Mahood AL (2017) Human-started wildfires expand the fire niche across the United States. Proceedings of the National Academy of Sciences 114: 2946-2951. https://doi.org/10.1073/pnas.1617394114

Balch JK, Bradley BA, D’Antonio CM, Gómez-Dans J (2013) Introduced annual grass increases regional fire activity across the arid western USA (1980-2009). Global Change Biology 19: 173-183. https://doi.org/10.1111/gcb.12046

Barnosky AD, Matzke N, Tomiya S, Wogan GOU, Swartz B, Quental TB, Marshall C, McGuire JL, Lindsey EL, Maguire KC, Mersey B, Ferrer EA (2011) Has the Earth's sixth mass extinction already arrived? Nature 471: 51-57. https://doi.org/10.1038/nature09678

Baruch Z, Ludlow MM, Davis R (1985) Photosynthetic responses of native and introduced C 4 grasses from Venezuelan savannas. Oecologia 67: 388-393. https://doi.org/10.1007/ BF00384945

Bilbao B, Medina E (1990) Nitrogen-use efficiency for growth in a cultivated African grass and a native South American pasture grass. Journal of Biogeography 17: 421-425. https://doi. org/10.2307/2845372

Bishop TBB, Gill RA, McMillan BR, Clair SBS (2020) Fire, rodent herbivory, and plant competition: implications for invasion and altered fire regimes in the Mojave Desert. Oecologia 192: 155-167. https://doi.org/10.1007/s00442-019-04562-2

Blackhall M, Raffaele E (2019) Flammability of Patagonian invaders and natives: When exotic plant species affect live fine fuel ignitability in wildland-urban interfaces. Landscape and Urban Planning 189: 1-10. https://doi.org/10.1016/j.landurbplan.2019.04.002

Bowman DMJS, Balch J, Artaxo P, Bond WJ, Cochrane MA, D’Antonio CM, DeFries R, Johnston FH, Keeley JE, Krawchuk MA, Kull CA, Mack M, Moritz MA, Pyne S, Roos CI, Scott AC, Sodhi NS, Swetnam TW (2011) The human dimension of fire regimes on Earth. Journal of Biogeography 38: 2223-2236. https://doi.org/10.1111/j.1365-2699.2011.02595.x

Bradley BA (2010) Assessing ecosystem threats from global and regional change: hierarchical modeling of risk to sagebrush ecosystems from climate change, land use and invasive species in Nevada, USA. Ecography 33: 198-208. https://doi.org/10.1111/j.1600-0587.2009.05684.x 
Bradley BA, Mustard JF (2005) Identifying land cover variability distinct from land cover change: cheatgrass in the Great Basin. Remote Sensing of Environment 94: 204-213. https://doi.org/10.1016/j.rse.2004.08.016

Brooks ML (1999) Alien annual grasses and fire in the Mojave Desert. Madrońo 46: 13-19.

Brooks ML (2002) Peak fire temperatures and effects on annual plants in the Mojave

Desert. Ecological Applications 12: 1088-1102. https://doi.org/10.1890/10510761(2002)012[1088:PFTAEO]2.0.CO;2

Brooks ML (2008) Plant invasions and fire regimes. In: Zouhar K, Smith JK, Sutherland S, Brooks ML (Eds) Wildland fire in Ecosystems: Fire and Nonnative Invasive Plants. General Technical Report RMRS-GTR-42-vol. 6. U.S. Department of Agriculture, Forest Service, Rocky Mountain Research Station, Ogden, 33-46.

Brooks ML, D’Antonio CM, Richardson DM, Grace JB, Keeley JE, DiTomaso JM, Hobbs RJ, Pellant M, Pyke D (2004) Effects of invasive alien plants on fire regimes. BioScience 54: 677-688. https://doi.org/10.1641/0006-3568(2004)054[0677:EOIAPO]2.0.CO;2

Brown DE, Minnich RA (1986) Fire and changes in creosote bush scrub of the western Sonoran Desert, California. American Midland Naturalist 116: 411-422. https://doi. org/10.2307/2425750

Busch DE (1995) Effects of fire on southwestern riparian plant community structure. The Southwestern Naturalist 40: 259-267.

Cansler CA, McKenzie D (2014) Climate, fire size, and biophysical setting control fire severity and spatial pattern in the northern Cascade Range, USA. Ecological Applications 24: 1037-1056. https://doi.org/10.1890/13-1077.1

Chun YJ, Van Kleunen M, Dawson W (2010) The role of enemy release, tolerance and resistance in plant invasions: linking damage to performance. Ecology Letters 13: 937-946. https://doi.org/10.1111/j.1461-0248.2010.01498.x

Chambers JC, Brooks ML, Germino MJ, Maestas JD, Board DI, Jones MO, Allred BW (2019) Operationalizing resilience and resistance concepts to address invasive grass-fire cycles. Frontiers in Ecology and Evolution 7: 1-185. https://doi.org/10.3389/fevo.2019.00185

Clavel J, Julliard R, Devictor V (2010) Worldwide decline of specialist species: toward a global functional homogenization? Frontiers in Ecology and the Environment 9: 222-228. https://doi.org/10.1890/080216

Cóbar-Carranza AJ, García RA, Pauchard A, Peña E (2014) Effect of Pinus contorta invasion on forest fuel properties and its potential implications on the fire regime of Araucaria araucana and Nothofagus antarctica forests. Biological Invasions 16: 2273-2291. https://doi.org/10.1007/s10530-014-0663-8

Cramer W, Bondeau A, Woodward FI, Prentice IC, Betts RA, Brovkin V, Cox PM, Fisher V, Foley JA, Friend AD, Kucharik C, Lomas MR, Ramankutty N, Sitch S, Smith B, White A, Young-Molling C (2001) Global response of terrestrial ecosystem structure and function to $\mathrm{CO}_{2}$ and climate change: results from six dynamic global vegetation models. Global Change Biology 7: 357-373. https://doi.org/10.1046/j.1365-2486.2001.00383.x

D’Antonio CM, Vitousek PM (1992) Biological invasions by exotic grasses, the grass/fire cycle, and global change. Annual Review of Ecology and Systematics 23: 63-87. https://doi. org/10.1146/annurev.es.23.110192.000431 
Dibble AC, White RH, Lebow PK (2007) Combustion characteristics of north-eastern USA vegetation tested in the cone calorimeter: invasive versus non-invasive plants. International Journal of Wildland Fire 16: 426-443. https://doi.org/10.1071/WF05103

Eilts JA, Huxman TE (2013) Invasion by an exotic, perennial grass alters responses of a native woody species in an arid system. Journal of Arid Environments 88: 206-212. https://doi. org/10.1016/j.jaridenv.2012.08.002

Ellis LM, Crawford CS, Molles Jr MC (1998) Comparison of litter dynamics in native and exotic riparian vegetation along the Middle Rio Grande of central New Mexico, USA. Journal of Arid Environments 38: 283-296. https://doi.org/10.1006/jare.1997.0334

Esler KJ, Holmes PM, Richardson DM, Witkowski ETF (2008) Riparian vegetation management in landscapes invaded by alien plants: insights from South Africa. South African Journal of Botany 74: 401-552. https://doi.org/10.1016/j.sajb.2008.01.168

Fisher JL, Loneragan WA, Dixon K, Delaney J, Veneklaas EJ (2009) Altered vegetation structure and composition linked to fire frequency and plant invasion in a biodiverse woodland. Biological Conservation 142: 2270-2281. https://doi.org/10.1016/j.biocon.2009.05.001

Fogarty G, FacelliJM (1999) Growth and competition of Cytisusscoparius, an invasiveshrub, and Australian native shrubs. Plant Ecology 144: 27-35. https:/doi.org/10.1023/A:1009808116068

Fulé PZ, Covington WW, Moore MM (1997) Determining reference conditions for ecosystem management of southwestern ponderosa pine forests. Ecological Applications 7: 895-908. https://doi.org/10.1890/1051-0761(1997)007[0895:DRCFEM]2.0.CO;2

Godfree R, Firn J, Johnson S, Knerr N, Stol J, Doerr V (2017) Why non-native grasses pose a critical emerging threat to biodiversity conservation, habitat connectivity and agricultural production in multifunctional rural landscapes. Landscape Ecology 32: 1219-1242. https://doi.org/10.1007/s10980-017-0516-9

Gray ME, Dickson BG, Zachmann LJ (2014) Modelling and mapping dynamic variability in large fire probability in the lower Sonoran Desert of south-western Arizona. International Journal of Wildland Fire 23: 1108. https://doi.org/10.1071/WF13115

Grigulis K, Lavorel S, Davies ID, Dossantos A, Lloret F, Vilà M (2005) Landscape-scale positive feedbacks between fire and expansion of the large tussock grass, Ampelodesmos mauritanica in Catalan shrublands. Global Change Biology 11: 1042-1053. https://doi.org/10.1111/ j.1365-2486.2005.00980.x

Grimm NB, Chapin III FS, Bierwagen B, Gonzalez P, Groffman PM, Luo Y, Melton F, Nadelhoffer K, Pairis A, Raymond PA, Schimel J, Williamson CE (2013) The impacts of climate change on ecosystem structure and function. Frontiers in Ecology and the Environment 11: 474-482. https://doi.org/10.1890/120282

Gunderson L (1999) Resilience, flexibility and adaptive management - antidotes for spurious certitude? Conservation Ecology 3: 1-7. https://doi.org/10.5751/ES-00089-030107

Hedges LV, Gurevitch J, Curtis PS (1999) The meta-analysis of response ratios in experimental ecology. Ecology 80:1150-1156.https://doi.org/10.1890/0012-9658(1999)080[1150:TM AORR]2.0.CO;2

Hernández E, Questad EJ, Meyer WM, Suding KN (2019) The effects of nitrogen deposition and invasion on litter fuel quality and decomposition in a Stipa pulchra grassland. Journal of Arid Environments 162: 35-44. https://doi.org/10.1016/j.jaridenv.2018.11.003 
Holling CS (1978) Adaptive environmental assessment and management. John Wiley \& Sons, New York, 377 pp.

James JJ, Drenovsky RE (2007) A basis for relative growth rate differences between native and invasive forb seedlings. Rangeland Ecology \& Management 60: 395-400. https://doi. org/10.2111/1551-5028(2007)60[395:ABFRGR]2.0.CO;2

Jauni M, Gripenberg S, Ramula S (2015) Non-native plant species benefit from disturbance: a meta-analysis. Oikos 124: 122-129. https://doi.org/10.1111/oik.01416

Johnstone JF, Allen CD, Franklin JF, Frelich LE, Harvey BJ, Higuera PE, Mack MC, Meentemeyer RK, Metz MR, Perry GLW, Schoennagel T, Turner MG (2016) Changing disturbance regimes, ecological memory, and forest resilience. Frontiers in Ecology and the Environment 14: 369-378. https://doi.org/10.1002/fee.1311

Keeley JE (2000) Fire and invasive species in Mediterranean-climate ecosystems of California. In: Galley, KEM, Wilson TP (Eds) Proceedings of the invasive species workshop: the role of fire in the control and spread of invasive species. Fire Conference 2000 11: 81-94.

Keeley JE, Brennan TJ (2012) Fire-driven alien invasion in a fire-adapted ecosystem. Oecologia 169: 1043-1052. https://doi.org/10.1007/s00442-012-2253-8

Kelley DI, Bistinas I, Whitley R, Burton C, Marthews TR, Dong N (2019) How contemporary bioclimatic and human controls change global fire regimes. Nature Climate Change 9: 690-696. https://doi.org/10.1038/s41558-019-0540-7

Kew RBG (2016) The state of the world's plants report - 2016. Royal Botanic Gardens, Kew.

Kraaij T, Baard JA, Arndt J, Vhengani L, Van Wilgen BW (2018) An assessment of climate, weather, and fuel factors influencing a large, destructive wildfire in the Knysna region, South Africa. Fire Ecology 14: 1-4. https://doi.org/10.1186/s42408-018-0001-0

Le Maitre DC, Kotzee IM, O'Farrell PJ (2014) Impacts of land-cover change on the water flow regulation ecosystem service: Invasive alien plants, fire and their policy implications. Land Use Policy 36: 171-181. https://doi.org/10.1016/j.landusepol.2013.07.007

Lippincott CL (2000) Effects of Imperata cylindrica (L.) Beauv. (Cogongrass) invasion on fire regime in Florida Sandhill (USA). Natural Areas Journal 20: 140-149.

Liu Z, Wimberly MC (2016) Direct and indirect effects of climate change on projected future fire regimes in the western United States. Science of The Total Environment 542: 65-75. https://doi.org/10.1016/j.scitotenv.2015.10.093

McDonald CJ, McPherson GR (2013) Creating hotter fires in the Sonoran Desert: buffelgrass produces copious fuels and high fire temperatures. Fire Ecology 9: 26-39. https://doi. org/10.4996/fireecology.0902026

McGranahan DA, Archibald S, Kirkman KP, O’Connor TG (2018) A native C3 grass alters fuels and fire spread in montane grassland of South Africa. Plant Ecology 219: 621-632. https://doi.org/10.1007/s11258-018-0822-6

McWethy DB, Higuera PE, Whitlock C, Veblen TT, Bowman DMJS, Cary GJ, Haberle SG, Keane RE, Maxwell BD, McGlone MS, Perry GLW, Wilmshurst JM, Holz A, Tepley AJ (2013) A conceptual framework for predicting temperate ecosystem sensitivity to human impacts on fire regimes. Global Ecology and Biogeography 22: 900-912. https://doi.org/10.1111/geb.12038

Melgoza G, Nowak RS, Tausch RJ (1990) Soil water exploitation after fire: competition between Bromus tectorum (cheatgrass) and two native species. Oecologia 83: 7-13. https:// doi.org/10.1007/BF00324626 
Miller G, Friedel M, Adam P, Chewings V (2010) Ecological impacts of buffel grass (Cenchrus ciliaris L.) invasion in central Australia - does field evidence support a fire-invasion feedback? The Rangeland Journal 32: 353-365. https://doi.org/10.1071/RJ09076

Moles AT, Gruber MAM, Bonser SP (2008) A new framework for predicting invasive plant species. Journal of Ecology 96: 13-17.

Myneni RB, Keeling CD, Tucker CJ, Asrar G, Nemani RR (1997) Increased plant growth in the northern high latitudes from 1981 to 1991. Nature 386: 698-702. https://doi. org/10.1038/386698a0

Pausas JG (1999) Response of plant functional types to changes in the fire regime in Mediterranean ecosystems: a simulation approach. Journal of Vegetation Science 10: 717-722. https://doi.org/10.2307/3237086

Pausas JG, Fernández-Muñoz S (2012) Fire regime changes in the Western Mediterranean Basin: from fuel-limited to drought-driven fire regime. Climatic Change 110: 215-226. https://doi.org/10.1007/s10584-011-0060-6

Purvis A, Agapow P-M, Gittleman JL, Mace GM (2000) Nonrandom extinction and the loss of evolutionary history. Science 288:328-330. https://doi.org/10.1126/science.288.5464.328

Pyšek P, Jarošík V, Hulme PE, Pergl J, Hejda M, Schaffner U, Vilà M (2012) A global assessment of invasive plant impacts on resident species, communities and ecosystems: the interaction of impact measures, invading species' traits and environment. Global Change Biology 18: 1725-1737. https://doi.org/10.1111/j.1365-2486.2011.02636.x

Rahlao SJ, Milton SJ, Esler KJ, Van Wilgen BW, Barnard P (2009) Effects of invasion of firefree arid shrublands by a fire-promoting invasive alien grass (Pennisetum setaceum) in South Africa. Austral Ecology 34: 920-928. https://doi.org/10.1111/j.1442-9993.2009.02000.x

R Core Team (2020) R: A language and environment for statistical computing. R Foundation for Statistical Computing, Vienna. http://www.r-project.org

Rogers BM, Neilson RP, Drapek R, Lenihan JM, Wells JR, Bachelet D, Law BE (2011) Impacts of climate change on fire regimes and carbon stocks of the US Pacific Northwest. Journal of Geophysical Research: Biogeosciences 116: G3. https://doi.org/10.1029/2011JG001695

Rosenberg MS, Adams DC, Gurevitch J (2000) MetaWin: Statistical Software for Metaanalysis. Sinauer Associates, Sunderland, 133 pp.

Rossiter NA, Setterfield SA, Douglas MM, Hutley LB (2003) Testing the grass-fire cycle: alien grass invasion in the tropical savannas of northern Australia. Diversity and Distributions 9: 169-176. https://doi.org/10.1046/j.1472-4642.2003.00020.x

Schoennagel T, Balch JK, Brenkert-Smith H, Dennison PE, Harvey BJ, Krawchuk MA, Mietkiewicz N, Morgan P, Moritz MA, Rasker R, Turner MG, Whitlock C (2017) Adapt to more wildfire in western North American forests as climate changes. Proceedings of the National Academy of Sciences 114: 4582-4590. https://doi.org/10.1073/ pnas. 1617464114

Schwartz MW, Hellmann JJ, McLachlan JM, Sax DF, Borevitz JO, Brennan J, Camacho AE, Ceballos G, Clark JR, Doremus H, Early R, Etterson JR, Fielder D, Gill JL, Gonzalez P, Green N, Hannah L, Jamieson DW, Javeline D, Minteer BA, Odenbaugh J, Polasky S, Richardson DR, Root TL, Safford HD, Sala O, Schneider HS, Thompson AR, Williams JW, Vellend M, Vitt P, Zellmer S (2012) Managed relocation: integrating the scientific, regulatory, and ethical challenges. BioScience 62: 732-743. https://doi.org/10.1525/bio.2012.62.8.6 
Seebens H, Blackburn TM, Dyer EE, Genovesi P, Hulme PE, Jeschke JM, Pagad S, Pyšek P, Winter M, Arianoutsou M, Bacher S (2017) No saturation in the accumulation of alien species worldwide. Nature Communications 8: 1-9. https://doi.org/10.1038/ncomms14435

Setterfield SA, Rossiter-Rachor NA, Hutley LB, Douglas MM, Williams RJ (2010) Turning up the heat: the impacts of Andropogon gayanus (gamba grass) invasion on fire behaviour in northern Australian savannas. Diversity and Distributions 16: 854-861. https://doi. org/10.1111/j.1472-4642.2010.00688.x

Stevens JT, Beckage B (2009) Fire feedbacks facilitate invasion of pine savannas by Brazilian pepper (Schinus terebinthifolius). New Phytologist 184: 365-375 https://doi.org/10.1111/ j.1469-8137.2009.02965.x.

Stevens JM, Fehmi JS (2009) Competitive effect of two nonnative grasses on a native grass in southern Arizona. Invasive Plant Science and Management 2: 379-385. https://doi. org/10.1614/IPSM-09-022.1

Syphard AD, Keeley JE, PfaffAH, Ferschweiler K (2017) Human presence diminishes the importance of climate in driving fire activity across the United States. Proceedings of the National Academy of Sciences 114: 13750-13755. https://doi.org/10.1073/pnas.1713885114

Syphard AD, Radeloff VC, Keuler NS, Taylor RS, Hawbaker TJ, Stewart SI, Clayton MK (2008) Predicting spatial patterns of fire on a southern California landscape. International Journal of Wildland Fire 17: 602-613. https://doi.org/10.1071/WF07087

Underwood EC, Klinger RC, Brooks ML (2019) Effects of invasive plants on fire regimes and postfire vegetation diversity in an arid ecosystem. Ecology and Evolution 9: 12421-12435. https://doi.org/10.1002/ece3.5650

Van Wilgen BW, Richardson DM (1985) The effects of alien shrub invasions on vegetation structure and fire behaviour in South African fynbos shrublands: a simulation study. Journal of Applied Ecology 22: 955-966. https://doi.org/10.2307/2403243

Westerling AL (2016) Increasing western US forest wildfire activity: sensitivity to changes in the timing of spring. Philosophical Transactions of the Royal Society B: Biological Sciences 371: 20150178. https://doi.org/10.1098/rstb.2015.0178

Westerling AL, Hidalgo HG, Cayan DR, Swetnam TW (2006) Warming and earlier spring increase western US forest wildfire activity. Science 313: 940-943. https://doi.org/10.1126/ science. 1128834

Whisenant SG (1990) Changing fire frequencies on Idaho's Snake River Plains: ecological and management implications. In: McArthur ED, Romney EM, Smith SD, Tueller PT (Eds) Proceeding-Symposium on cheatgrass invasion, shrub die-off, and other aspects of shrub biology and management, USDA Forest Service Intermountain Research Station General Technical Report INT-276: 4-10.

Williams BK, Brown ED (2012) Adaptive management: the US Department of the Interior applications guide. US Department of the Interior, Adaptive Management Working Group.

Wilsey BJ, Polley HW (2006) Aboveground productivity and root-shoot allocation differ between native and introduced grass species. Oecologia 150: 300-309. https://doi. org/10.1007/s00442-006-0515-z

Wilson AM, Latimer AM, Silander JA, Gelfand AE, De Klerk H (2010) A hierarchical Bayesian model of wildfire in a Mediterranean biodiversity hotspot: implications of weather variability and global circulation. Ecological Modelling 221: 106-112. https://doi.org/10.1016/j. ecolmodel.2009.09.016 